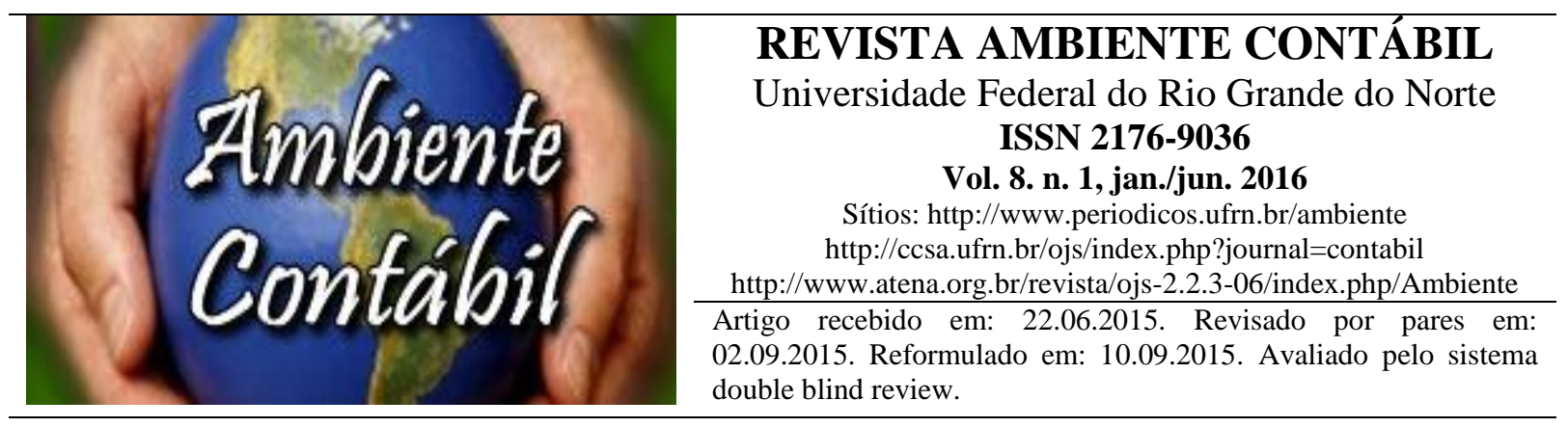

\title{
PECULIARIDADES DA ARRECADAÇÃO E COBRANÇA DA DÍVIDA ATIVA NA ADMINISTRAÇÃO PÚBLICA
}

\section{PECULIARITIES OF LEVY AND TAX REVENUES OF ACTIVE DEBT IN PUBLIC ADMINISTRATION}

\section{PARTICULARIDADES DE LA RECAUDACIÓN Y COBRODE LA DEUDA ACTIVA EN LA ADMINISTRACIÓN PÚBLICA}

\author{
Autores \\ Gustavo Afonso Santi Rossi \\ Mestrando em Ciências Contábeis (FAF/UERJ) e Bacharel em Ciências Contábeis (FACC/UFRJ). \\ Endereço: Rua São Francisco Xavier, 524, $9^{\circ}$ Andar, Bloco E - Maracanã, Rio de Janeiro-RJ. Brasil. \\ CEP: 20550-013. Telefone: 55-21-2334-0294. \\ E-mail: gustavo.rossi1@gmail.com \\ Waldir Jorge Ladeira dos Santos \\ Doutor em Políticas Públicas (PPFH/UERJ), Professor Adjunto do Programa de Mestrado \\ (FAF/UERJ) e Professor Adjunto da FACC/UFRJ. Endereço: Rua São Francisco Xavier, 524, $9^{\circ}$ \\ Andar, Bloco E - Maracanã, Rio de Janeiro-RJ. Brasil. CEP: 20550-013. Telefone: 55-21-2334-0294. \\ E-mail:wcladeira@uol.com.br
}

\section{RESUMO}

Este trabalho tem como objetivo geral analisar as principais ações realizadas pelo Estado do Rio de Janeiro na gestão do estoque da dívida ativa, no período de 2010 a 2014. Trata-se de uma abordagem baseada na pesquisa quantitativa. Quanto às formas e procedimentos utilizaram-se os métodos documental e bibliográfico. Dentre os resultados do trabalho observou-se a existência de sensibilidade moderada entre as variáveis de provisão e registros dos estoques das Dívidas Ativas Tributária e Não Tributária, de acordo com os testes estatísticos. O Estado do Rio de Janeiro ainda não utiliza o regime de competência nos registros dos créditos da dívida ativa tributária, entretanto a reciproca não é verdadeira para os créditos de dívida ativa não tributária. O Estado do Rio de Janeiro realiza a mensuração do ajuste para perdas com créditos em dívida ativa, refletindo o cerne dos princípios da oportunidade e da prudência. O crescimento do estoque de dívida ativa tem forte influência sobre os trâmites legais que o regem com a obediência dos prazos decadenciais e prescricionais que o fisco dispõe para suas atividades de cobranças das receitas públicas. Parte do consumo do estoque se deu por ações de saneamento de determinados créditos considerados incobráveis acarretando em alguns casos o cancelamento de certidões. Outra forma de consumo do estoque ocorreu mediante política de renúncia de receita de anistias e remissões de pagamentos aos sujeitos passivos da obrigação. Por fim, o acervo expressivo de processos nas varas de fazenda pública do judiciário espelha que grande parte dos créditos 
inscritos em dívida ativa está em fase de litígio e com efeito de suspensão, quanto à expectativa de recebimento, justificando, em parte, a necessidade de um controle contínuo sobre a idade, expectativa de recebimento e ganho da ação.

Palavras-chave: Dívida Ativa. Arrecadação. Cobrança. Registro. Regimes Contábeis.

\begin{abstract}
This work has as main objective to analyze the main actions carried out by the State of Rio de Janeiro in inventory management of outstanding debt in the period 2010 to 2014. It is an approach based on quantitative research. As regards the methods and procedures used the documentary and bibliographical methods. Among the results of the work we observed the existence of moderate sensitivity between the provision of variables and records of stocks of Tax Debt and Tax Not Active, according to statistical tests. The state of Rio de Janeiro still does not use the accrual basis in the records of the tax credits outstanding debt, but the reciprocal is not true for non-tax debts owed credits. The state of Rio de Janeiro performs the measurement of adjustment for credit losses on outstanding debt, reflecting the core principles of opportunity and prudence. The growth of outstanding debt stock has strong influence on the legal procedures that govern it with the obedience of limitation periods that the tax authorities have for your collection of public revenue activities. Of the stock of consumption occurred for sanitation actions of credits deemed irrecoverable leading in some cases the cancellation of certificates. Another form of inventory consumption occurred through amnesties revenue waiver policy and remissions of payments to the obligation of taxpayers. Finally, the significant collection processes in public the judiciary farm sticks reflects that most of the appropriations entered in outstanding debt is in dispute and suspension effect phase, as the expectation of receiving, justifying in part the need to a continuous control over the old expectation of receiving and gain share.
\end{abstract}

Keywords: Active Debt. Tax Revenues. Levy. Record. Accounting Schemes.

\title{
RESUMEN
}

Este trabajo tiene como principal objetivo analizar las principales actuaciones llevadas a cabo por el Estado de Río de Janeiro en la gestión del inventario de la deuda pendiente en el período de 2010 a 2014. Se trata de un enfoque basado en la investigación cuantitativa. En cuanto a los métodos y procedimientos utilizados documental y métodos bibliográficas. Entre los resultados del trabajo se observó la existencia de sensibilidad moderada entre la provisión de variables y registros de existencias de Deuda Fiscal y No Fiscal está activo, de acuerdo con las pruebas estadísticas. El estado de Rio de Janeiro todavía no utiliza el criterio de lo devengado en los registros de los créditos fiscales deuda pendiente, pero el recíproco no es cierto para las deudas no fiscales créditos adeudados. El estado de Rio de Janeiro realiza la medición del ajuste por pérdidas de crédito de la deuda en circulación, lo que refleja los principios básicos de la oportunidad y la prudencia. El crecimiento de la deuda en circulación tiene una fuerte influencia en los procedimientos legales que la rigen con la obediencia de los períodos limitación de que las autoridades fiscales tienen para su colección de actividades generadoras de ingresos públicos. De las acciones de consumo se produjo a las acciones de saneamiento de créditos considerados irrecuperables que en algunos casos la cancelación de los certificados. Otra forma de consumo de inventarios se produjo a través de los ingresos amnistías políticas renuncia y remisiones de los pagos a la obligación de los contribuyentes. Por último, los procesos de recolección significativas en públicos los palos agrícolas poder judicial refleja que la mayor parte de los créditos consignados en la deuda pendiente se encuentra en fase de litigio y el efecto de suspensión, según la expectativa de recibir, lo que justifica, en parte, la necesidad de un control continuo sobre la antigua expectativa de recibir y compartir. 
Palabras clave: Deuda Activa. Recaudación. Cobro. Registro. Regímenes de Contables.

\section{INTRODUÇÃO}

A dívida ativa, classificada como receita corrente, é um crédito de receitas públicas provenientes do não pagamento aos cofres públicos representando um direito a receber assegurado ao Estado. Demonstra-se na sua essência como frustração diferida de arrecadação tendo relação direta nas prioridades e metas da Administração Pública, no que se refere às consecuções de seus objetivos para execução orçamentária de suas políticas públicas em determinado período (OLIVEIRA, 2013).

Os direitos a receber da Administração, referentes às dívidas tributárias e não tributárias vencidas e não pagas, têm suas particularidades e complexidades quando analisados pelas óticas normativas e procedimentais. Isso se reflete no lapso temporal do ciclo da dívida ativa, desde a ocorrência do fato gerador da obrigação do crédito tributário ou não tributário, passando pelos prazos decadencial e prescricional de 5 (cinco) anos cada, em regra, até as ações de cobranças administrativas e execuções realizadas pelo Judiciário.

Neste sentido manter um controle interno eficiente sobre os referidos créditos é de suma importância para garantir seus recebimentos e cultivar o sentimento de justiça fiscal aos "bons pagadores".

No setor público, à época da prevalência do enfoque orçamentário, os registros das receitas públicas eram feitos pelo regime de caixa, sem o prévio registro do valor a receber. Com a mudança sobre a ótica do objeto da contabilidade pública para o enfoque patrimonial, o controle na contabilidade permitiu evidenciar os montantes de créditos desta natureza, tendo em vista, como regra, a adoção do regime de competência. Diante deste fato, surge o problema de pesquisa: Como se deu as adaptações dos novos procedimentos dados pelas alterações normativas aplicáveis ao Setor Público sobre a ótica da dívida ativa?

Este trabalho tem como objetivo geral analisar as principais ações realizadas pelo Estado do Rio de Janeiro na gestão do estoque da dívida ativa, no período de 2010 a 2014.

Para cumprimento do objetivo geral são apresentados os seguintes objetivos específicos:

- Analisar a sensibilidade existente entre as variáveis Divida Ativa Tributária, Dívida Ativa Não Tributária e Provisão para Perdas de Dívida Ativa;

- Identificar se os principais eventos para a escrituração da dívida ativa adotados pelo Estado do Rio de Janeiro estão em consonância com as normas vigentes aplicáveis ao Setor Público;

- Acompanhar a evolução dos saldos patrimoniais pertinentes à dívida ativa;

- Mencionar ações inerentes à cobrança, ao controle e à arrecadação que resultem na mutação do estoque da dívida ativa.

Tais objetivos específicos contribuirão para a busca do objetivo geral por subsidiarem informações relevantes às avaliações quantitativas e qualitativas sobre arrecadação, controle e cobrança propostos pela pesquisa.

Justifica-se este estudo pela carência de estudos acadêmicos sobre a temática, bem como pelo interesse de realizar o levantamento dos principais impactos no sistema patrimonial decorrente das novas tratativas dadas à matéria dívida ativa pelo Manual de Contabilidade Aplicada ao Setor Público (MCASP).

Dando sequência à introdução encontra-se o referencial teórico sobre receita pública e suas etapas até chegar à dívida ativa. Em continuação, expõe-se a metodologia, com análise do caso para, por fim, chegar-se à conclusão seguida, pelas referências bibliográficas. 


\section{REFERENCIAL TEÓRICO}

Para melhor interpretação do assunto dívida ativa segregou-se este tópico em duas partes: ciclo da dívida ativa e aspectos e regimes orçamentários e patrimoniais da contabilidade aplicada ao setor público.

\subsection{CICLO DA DÍVIDA ATIVA}

A Constituição Federal de 1988, em seu artigo 163, prescreve que Lei Complementar disporá sobre finanças públicas. As leis que regulamentaram tais assuntos foram: Leis $\mathrm{n}^{\mathrm{o}}$ 4.320, de 17 de março de 1964 e Lei Complementar $n^{\circ} 101$, de 04 de maio de 2000.

A Lei $n^{0} 4.320 / 64$, reconhecida como marco histórico, foi recepcionada pela Constituição com status de Lei Complementar devido ao seu conteúdo material. Trata-se de Normas Gerais de Direito Financeiro para elaboração e controle dos orçamentos e balanços da Administração Pública em sentido latu, tendo como principal instrumento o orçamento público. Dentre outros assuntos a dívida ativa é tratada neste diploma legal, sendo base legislativa para outros normativos.

Para tratar do assunto dívida ativa deve-se conhecer com clareza algumas classificações e conceitos sobre as receitas públicas. Neste contexto, para Jund (2006, p. 146) a receita pública "consiste no conjunto de ingressos financeiros, como fontes e fatos geradores próprios e permanentes, originados da ação e de tributos inerentes à instituição". Elas podem ser divididas em vários aspectos, como, por exemplo, em originárias e derivadas, classificação muito utilizada pela doutrina jurídica. Aquelas provêm da exploração do próprio patrimônio público, enquanto que as últimas decorrem da supremacia do Estado sobre os particulares, envolvendo patrimônio alheio e não o do próprio Estado (LIMA; CASTRO, 2007).

De maneira latu, Kohama (2006) segrega as receitas públicas em dois grandes grupos, orçamentárias e extraorçamentárias, como pertencentes ou não ao Estado, respectivamente.

Vicari Junior et al. (2003) apontam uma das principais classificações orçamentárias: receitas corrente e de capital. Estas decorrem de natureza contratual e eventual e não afetam a situação líquida do ente. Já aquelas têm natureza contínua, cuja essência na supremacia do interesse público sobre o privado materializa-se, em regra, no poder tributante do Estado.

Outro entendimento importante para a sistemática do ciclo da dívida ativa deriva das etapas ou fases da receita pública. O MCASP (2015) divide as receitas orçamentárias públicas nas fases de planejamento e execução. Na fase do planejamento tem-se a previsão, enquanto que na fase da execução há as etapas de lançamento, arrecadação e recolhimento.

O planejamento "compreende a previsão de arrecadação da receita orçamentária constante na Lei Orçamentária Anual (LOA), resultante de metodologias de projeção usualmente adotadas, observadas as disposições constantes da Lei de Responsabilidade Fiscal (LRF)" (MCASP, 2015, p. 49).

Para Kohama (2001, p. 97) a previsão "corresponde aos valores que a lei do orçamento consignar, pois são estimativas de receitas que se originam de estudos de previsão, antes de comporem o projeto de lei orçamentária".

De acordo com o artigo 12 da LRF a previsão de receita resume-se em planejar e estimar a arrecadação das receitas orçamentárias contidas na proposta de lei orçamentária anual.

Artigo 12. As previsões de receita observarão as normas técnicas e legais, considerarão os efeitos das alterações na legislação, da variação do índice de preços, do crescimento econômico ou de qualquer outro fator relevante e serão acompanhadas de demonstrativo de sua evolução nos últimos três anos, da projeção para os dois seguintes àquele a que se referirem, e da metodologia de cálculo e premissas utilizadas. 
Quanto à etapa de execução, como dito, existem três estágios: o lançamento, a arrecadação e o recolhimento.

Em consonância com o artigo 142, do Código Tributário Nacional (CTN), o lançamento é procedimento administrativo, que identifica o sujeito passivo e apura o montante do tributo devido, tendo em vista a ocorrência do fato gerador. Kohama (2001) conceitua lançamento como ato administrativo, emanado do Poder Público, que visa identificar os aspectos materiais e formais, bem como caracteres qualitativos e quantitativos do sujeito passivo.

O MCASP (2015, p. 50) ressalta que "segundo o disposto nos artigos 142 a 150 do CTN, a etapa de lançamento situa-se no contexto de crédito tributário, ou seja, aplica-se a impostos, taxas e contribuição de melhoria". O referido Manual ainda complementa que, "de acordo com o artigo 52 da Lei $\mathrm{n}^{0} 4.320 / 64$, são objeto de lançamento as rendas com vencimento determinado em lei, regulamento ou contrato".

Já o estágio da arrecadação está refletido no inciso I, artigo 35 da Lei n ${ }^{\circ} 4.320$, de 17 de março de 1964, espelhando o regime de caixa, donde prescreve que pertencem ao exercício financeiro as receitas nele arrecadadas.

O artigo 56 da Lei $\mathrm{n}^{\circ} 4.320 / 64$ trata da fase de recolhimento.

Artigo 56. O recolhimento de todas as receitas far-se-á em estrita observância ao princípio de unidade de tesouraria, vedada qualquer fragmentação para criação de caixas especiais.

Infere-se que a arrecadação e recolhimento são fases que se complementam, pois com o avanço da tecnologia da informação no âmbito da Administração Pública, cada vez mais há a dificuldade da compreensão e segregação dessas etapas (KOHAMA, 2001).

Neste contexto, quando ocorrer o não cumprimento da obrigação do pagamento dos créditos de natureza tributária ou não favoráveis à Fazenda Pública, por parte do sujeito passivo, ficarão pendentes as ações e esforços da Administração Pública compreendidas nas etapas de arrecadação e recolhimento.

Após apurada a liquidez e certeza dos créditos de natureza tributária ou não tributária, exigíveis pelo transcurso do prazo de pagamento, deverão ser inscritos, como Dívida Ativa, em registro próprio $\left(\$ 1^{\circ}\right.$, artigo 39 , Lei $\left.\mathrm{n}^{\circ} 4.320 / 64\right)$.

Os conceitos de dívida ativa tributária e não tributária foram tratados no $\S 2^{\circ}$ do artigo 39, da Lei no 4.320/64:

Dívida Ativa Tributária é o crédito da Fazenda Pública dessa natureza, proveniente de obrigação legal relativa a tributos e respectivos adicionais e multas, e Dívida Ativa não Tributária são os demais créditos da Fazenda Pública, tais como os provenientes de empréstimos compulsórios, contribuições estabelecidas em lei, multa de qualquer origem ou natureza, exceto as tributárias, foros, laudêmios, aluguéis ou taxas de ocupação, custas processuais, preços de serviços prestados por estabelecimentos públicos, indenizações, reposições, restituições, alcances dos responsáveis definitivamente julgados, bem assim os créditos decorrentes de obrigações em moeda estrangeira, de sub-rogação de hipoteca, fiança, aval ou outra garantia, de contratos em geral ou outras obrigações legais.

Oliveira (2013) sintetiza bons argumentos à temática classificando a dívida ativa como receita corrente e fonte de recursos diferida, proveniente da frustação de arrecadação e controle na cobrança, tornando-se de extrema importância para que o Poder Público seja eficaz, para a consecução do bem estar social.

O Manual de Contabilidade Aplicada ao Setor Público (MCASP) que está na sua $6^{\mathbf{a}}$ versão, editado pela Secretaria do Tesouro Nacional (STN), surgiu com intuito de buscar a 
padronização dos procedimentos contábeis nos três níveis de governo, através da orientação e apoio à gestão patrimonial, visando, ainda, à consolidação de conceitos, regras e procedimentos de reconhecimento contábil de operações típicas do setor público.

O MCASP $(2015$, p. 256) conceitua a dívida ativa como um

\begin{abstract}
conjunto de créditos tributários e não tributários em favor da Fazenda Pública, não recebidos no prazo para pagamento definitivo em lei ou em decisão proferida em processo regular, inscrito pelo órgão ou entidade competente, após apuração de certeza e liquidez. É uma fonte potencial de fluxo de caixa e é reconhecida contabilmente no ativo. Não se confunde com a dívida pública, uma vez que esta representada as obrigações do ente público com terceiros e é reconhecida contabilmente no passivo.
\end{abstract}

Para Kohama (2006, p. 84) "constituem Dívida Ativa a importância relativa a tributos, multa e créditos da Fazenda Pública, lançados, mas não recebidos no prazo do vencimento, a partir da data de sua inscrição".

Vicari Junior et al. (2003) sintetizam os referidos conceitos ao relacionar a dívida ativa tributária à obrigação legal tributária e suas obrigações acessórias; já as não tributárias se relacionam com as demais obrigações do sujeito passivo para com o Estado, contratuais ou por equiparação legal.

"Com a promulgação da LRF inicia-se um marco definitivo no caminho da transparência e moralização da atividade pública brasileira [...] Esta lei alterou definitivamente o comportamento dos administradores públicos quanto à forma de gerirem o patrimônio da coisa pública" (DALFOVO; MAÇANEIRO, 2008).

A LC $n^{0} 101 / 00$ - Lei de Responsabilidade Fiscal - prescreve normas de finanças públicas voltadas para a responsabilidade na gestão físcal estabelecendo limites de dívida consolidada, garantias, operações de créditos, restos a pagar e despesas com pessoal, objetivando garantir o equilíbrio das finanças públicas, além de instituir instrumentos de transparência na gestão fiscal.

Nesse sentido, há o entendimento pela jurisprudência dos Tribunais de Contas que a inércia da Administração Pública no controle e cobrança da dívida ativa caracteriza omissão de receita, pois de acordo com Oliveira (2013, p. 12) "a não cobrança da dívida ativa, além de implicar no não ingresso de receita pública ao Erário, acaba por estimular o surgimento de novos inadimplentes, em decorrência, especialmente, da inércia do Poder Público, que acaba por gerar a impressão da impunidade".

Giuberti (2010, p. 24) ressalta que

os prazos de que o Fisco dispõe para a cobrança dos tributos não pagos são: cinco anos para inscrever o crédito em dívida ativa, emitir a CDA, e, após a inscrição, mais cinco anos para entrar com o processo judicial de cobrança. O recebimento neste caso ocorre após o fim do processo judicial, seja por acordo, seja por sentença do juiz.

Por conta deste intervalo de tempo deve-se proceder com o ajuste do estoque de dívida ativa de acordo com a expectativa de recebimento. O MCASP (2015, p. 267) orienta que "a mensuração do ajuste para perdas deve basear-se em estudos especializados que delineiem e qualifiquem os créditos inscritos, de modo a não superestimar e nem subavaliar o patrimônio real do ente público". O MCASP (2015) ratifica que deverão ser mencionadas nas notas explicativas das Demonstrações tanto a metodologia adotada como a memória de cálculo do ajuste para perdas, como forma de dar cumprindo à transparência da gestão pública.

Para Darós e Pereira (2009) a NBCASP "estabelece critérios e procedimentos para a mensuração de ativos e passivos integrantes do Patrimônio de entidades do setor público." Os autores destacam, ainda, a avaliação patrimonial como sendo "a atribuição de valor monetário 
a itens do ativo e passivo decorrentes de julgamento fundamentado em consenso entre as partes e que traduza, com razoabilidade, a evidenciação dos atos e dos fatos administrativos".

Castro e Garcia (2004) comentam sobre a existência, na área pública, de sistemas informatizados para controle da dívida ativa com a interação do setor de contabilidade, conciliando, desta forma, o saldo contábil com tais sistemas. Esse controle gera, de regra, um resumo que consubstanciará os lançamentos contábeis, mantendo supervisão efetiva sobre os valores passíveis de diferimento quanto à expectativa de recebimento.

\subsection{ASPECTOS E REGIMES ORÇAMENTÁRIO E PATRIMONIAL DA CONTABILIDADE APLICADA AO SETOR PÚBLICO}

De acordo com o MCASP (2015, p. 24) o aspecto orçamentário "compreende o registro e a evidenciação do orçamento público, tanto à sua aprovação quanto à sua execução".

Castro e Garcia (2004) afirmam que na área pública o enfoque está no orçamento e nas finanças. Tendo em vista que este baliza o cumprimento dos compromissos assumidos, enquanto que aquele é a própria essência do gasto público. Em linha similar Kohama (2001) afirma que o sistema orçamentário evidencia os aspectos da Lei Orçamentária Anual (LOA) e dos Créditos Adicionais, bem como sua execução.

Diferentemente o aspecto patrimonial reflete a aplicação dos princípios e das normas contábeis relacionadas aos procedimentos de reconhecimento, mensuração e evidenciação dos ativos e passivos e das variações patrimoniais do ente público (MCASP, 2015).

Segundo Kohama (2001, p. 51) o sistema patrimonial "registra analiticamente todos os bens de caráter permanente, com indicação dos elementos necessários para a perfeita caracterização de cada um deles e dos agentes responsáveis pela sua guarda e administração, bem como mantém registro sintético dos bens móveis e imóveis".

Darós e Pereira (2009) abordam as Normas Brasileiras de Contabilidade Aplicadas ao Setor Público (NBCASP) analisando os principais efeitos evidenciados nas demonstrações contábeis. Afirmam os autores que o

\footnotetext{
posicionamento da NBCASP demonstra um desprendimento do foco estritamente orçamentário, e serve como reforço para a implementação de uma contabilidade pública com visão patrimonial, que evidencie a totalidade dos os atos e fatos, orçamentários e extraorçamentários, previstos ou não em legislação, de modo que prevaleça a essência da Ciência Contábil, qual seja a de evidenciar as alterações no patrimônio da entidade.
}

O inciso I, artigo 35, da Lei $\mathrm{n}^{0}$ 4.320/64, evidencia o registro das receitas orçamentárias pelo regime de caixa. Kohama (2001) comenta que pelo texto legal deve-se utilizar o regime de caixa, em relação ao regime contábil de escrituração, devendo-se considerar apenas a receita que for efetivamente arrecada no exercício. Na mesma linha de raciocínio, Slomski (2003, p. 31) argumenta que, "no Brasil, o regime de escrituração contábil é o regime misto, qual seja, para a receita orçamentária o regime de caixa e para a despesa orçamentária o regime de competência".

Entretanto, no Título IX - Da Contabilidade, da Lei n ${ }^{0} 4.320 / 64$, está estabelecido que as variações patrimoniais, independentes ou resultantes de execução orçamentária, serão evidenciadas. "Nesse sentido, a contabilidade deve evidenciar, tempestivamente, os fatos ligados à administração orçamentária, financeira e patrimonial, gerando informações que permitam o conhecimento da composição patrimonial e dos resultados econômicos e financeiros de determinado exercício" (MCASP, 2015, p. 48). 
O MCASP (2015) segrega os Regimes da Contabilidade Aplicada ao Setor Público, em Orçamentário e Patrimonial, quanto ao fato gerador dos ingressos. No regime orçamentário, embasado no artigo 35, da Lei $\mathrm{n}^{\circ} 4.320 / 64$, o fato gerador da receita orçamentária é representado pela arrecadação (regime de caixa). Entretanto, no regime patrimonial, o fato gerador da variação patrimonial aumentativa é tido pelo regime de competência, em consonância com a Resolução do CFC n ${ }^{0}$ 750, de 1993.

Isso demonstra que durante muito tempo, pela interpretação da Lei $n^{0} 4.320 / 64$, o aspecto orçamentário foi entendido como principal protagonista na Administração Pública. Entretanto, com a harmonização dos procedimentos contábeis do Setor Público aos padrões internacionais, houve a busca pelo resgate da ênfase patrimonial, e não somente o controle do orçamento. Para isso necessitou-se de um trabalho de separação entre o orçamento e o patrimônio.

Feijó (2012) diz que o orçamento e a contabilidade pública possuem conceitos e objetivos diversos e independentes. A visão orçamentária relaciona-se com a de controle dos fluxos de ingressos e saídas de caixa. Entretanto, quando adquirido algum ativo torna-se a contabilidade responsável em controlá-lo e incorporá-lo ao patrimônio público. A Administração Pública, com esta diferenciação, mantém, então, o controle dos aspectos orçamentários e volta sua atenção ao patrimônio público e suas mutações.

Cruvinel e Lima (2011) entendem que

sob a perspectiva das NBCASP, em busca da Contabilidade com base na competência integral, o CFC tem enfatizado em cada uma de suas Normas Brasileiras de Contabilidade Aplicadas ao Setor Público os procedimentos contábeis que serão incorporados na rotina das transações governamentais. O MCASP tenta compatibilizar a visão orçamentária com a visão patrimonial.

Lima, Santana e Guedes (2009) citam que "as NBC T 16 estabelecem que as receitas e despesas devem ser reconhecidas pelos respectivos fatos geradores (competência integral), independentemente do momento da execução orçamentária".

Nesse conjunto, Quitana et. al (2011) argumentam que diante do contexto de financiamento dos serviços públicos

\begin{abstract}
o reconhecimento da receita pública deverá ser incluído na apuração do resultado no período em que ocorre independentemente do seu cumprimento. No entanto, considerado a execução financeira, e o artigo 35 da Lei $\mathrm{n}^{\circ} 4.320 / 64$, é comum encontrar nas bibliografias contábeis o entendimento de que na área pública o regime contábil adotado é um regime misto [...] Mas, a partir de um novo entendimento gerado pela edição das Normas Brasileiras de Contabilidade aplicadas ao Setor público, especialmente a NBC T 16.1, [...] deve-se entender que o impacto no patrimônio ocorre com o registro da receita em função de seu fato gerador, observando por consequência os Princípios Fundamentais de Contabilidade e o disposto na Lei $\mathrm{n}^{\circ}$ 4.320/64.
\end{abstract}

Percebe-se que a interpretação dada pela doutrina acerca dos registros contábeis das receitas públicas migrou do contexto orçamentário para o patrimonial, prevalecendo à essência sobre a forma, bem como o objeto da contabilidade como Ciência. De acordo com a posição trazida pelo MCASP (2015) e adotada por diversos doutrinadores nas Ciências Contábeis deve-se aceitar atualmente o regime de competência para as receitas públicas. No entanto, ressalta-se que nem toda receita deve ser registrada pelo regime de competência, mesmo se tratando dos impactos dados no subsistema patrimonial, pois as receitas que são passiveis deste tratamento são as oriundas dos artigos 142 a 150 do CTN e do artigo 52 da Lei $\mathrm{n}^{\mathrm{o}}$ 4.320/64. Logo, as receitas de capital, a título exemplificativo, que não passam pela etapa de lançamento continuam sendo registradas pelo regime de caixa. Isso contraria a linha de 
pensamento, em parte, de Quitana et al. (2011), MCASP (2015) e outras bibliografias que afirmam que as receitas devem ser registradas pelo regime de competência, de acordo com seu fato gerador.

\section{METODOLOGIA}

Quanto à abordagem, utilizou-se o tipo de pesquisa quantitativa, pois de acordo com Raupp e Beuren (2003) esta abordagem se caracteriza pelo emprego de instrumentos estatísticos.

Escolheu-se este método para estabelecer relações entre as principais variáveis independentes, contas patrimoniais de Dívida Ativa Tributária e Não Tributária, e a variável dependente, conta de Provisão para Perdas com Dívida Ativa. Neste sentido, aplicaram-se os testes de Estatística de Regressão Simples e de Interseção pela função ANOVA, com intuito de montar a equação de regressão sobre a correlação entre os saldos daquelas contas apresentadas pelo Governo do Estado do Rio de Janeiro nos Balancetes Mensais Consolidados.

O período de extração dos saldos patrimoniais foi de 5 (cinco) anos, de 2010 a 2014 pois ele abrange mais de uma legislatura do chefe do executivo estadual. Justifica-se este interregno como um acompanhamento da evolução dos saldos analisados, através da variação horizontal, interpretando-a quando os valores absolutos e ou relativos tiveram comportamentos expressivos.

Os Relatórios de Contas de Gestão estão disponíveis no Portal da Transparência do Governo do Estado do Rio de Janeiro no endereço web www.transparencia.rj.gov.br através do caminho: Portais do Estado do Rio de Janeiro - Contadoria; Relatórios de Contas de Gestão; Exercício. O endereço web direto para consulta está disponível: http://www.fazenda.rj.gov.br/sefaz/faces/menu_structure/sitios/sitios-contadoria-

navigation/folder3/url45?_afrLoop=666600302224000\&datasource=UCMServer\%23dDocNa me\%3A1170046\&_adf.ctrl-state=w9wg4xmcr_128

Como formas de procedimentos a pesquisa se enquadra em documental e bibliográfica, uma vez que, na visão de Pimentel (2001), quando os estudos tiverem em sua essência documentos consubstanciados por revisões bibliográficas, devidamente analisadas, organizando-os e interpretando-os segundo os objetivos empíricos, ter-se-ão as referidas formas de procedimentos.

Marconi e Lakatos (2005, p. 185) exemplificam que este tipo de pesquisa "abrange toda bibliografia já tornada pública em relação ao tema de estudo, desde publicações avulsas, boletins, jornais, revistas, livros, pesquisas, monografias, teses, material cartográfico etc., até meios de comunicações orais: rádio, gravações em fita magnética e audiovisuais: filmes e televisão".

Neste sentido, pelo fato do tema dívida ativa carecer de estudos acadêmicos, foram utilizadas normas e leis no sentido latu senso, livros, alguns artigos que trataram sobre a matéria até mesmo que de forma indireta, dissertação e entrevista publicada em sites da internet.

\section{DESCRIÇÃO E ANÁLISE DOS RESULTADOS}

O artigo $1^{\circ}$ da Portaria STN $n^{\circ} 828$, de 14 de dezembro de 2011 alterou o artigo $6^{\circ}$, da Portaria STN n ${ }^{\circ}$ 406, de 20 de junho de 2011 passando a vigorar com a seguinte redação: 
Artigo $6^{\circ}$ A Parte II - Procedimentos Contábeis Patrimoniais deverá ser adotada pelos entes da Federação gradualmente a partir do exercício de 2012 e integralmente até o final do exercício de 2014, salvo na existência de legislação específica emanada pelos órgãos de controle que antecipe este prazo, e a parte III Procedimentos Contábeis Específicos deverá ser adotada pelos entes de forma obrigatória a partir de 2012 .

O inciso I, do artigo $6^{\circ}$ da Portaria STN no 437 de 12 de junho de 2012, marca o momento em que foi obrigatório o reconhecimento, mensuração e evidenciação dos créditos, tributários ou não, por competência, e a dívida ativa, incluindo os respectivos ajustes para perdas.

Logo, infere-se que no decorrer exercício de 2014 passou-se a registrar os procedimentos de dívida ativa pelo regime de competência.

O MCASP (2015) trouxe algumas alterações relevantes sobre a temática em questão, dívida ativa, conforme detalhamento no quadro 1:

\begin{tabular}{|c|c|}
\hline ALTERAÇÃO & DESCRIÇÃO \\
\hline $\begin{array}{l}\text { Inclusão de Rotina de } \\
\text { Contabilização }\end{array}$ & Inclusão de rotina de contabilização do recebimento da dívida ativa de bens. \\
\hline $\begin{array}{l}\text { Inclusão de Rotina de } \\
\text { Encerramento }\end{array}$ & $\begin{array}{l}\text { Inclusão de rotina de encerramento das contas de controle ao final do exercício, } \\
\text { para os entes que as utilizam. }\end{array}$ \\
\hline $\begin{array}{l}\text { Inclusão de Procedimentos } \\
\text { para Contabilização }\end{array}$ & $\begin{array}{l}\text { Inclusão de procedimentos para contabilização da compensação entre créditos da } \\
\text { dívida ativa e créditos contra a Fazenda Pública. }\end{array}$ \\
\hline $\begin{array}{l}\text { Exclusão da Metodologia } \\
\text { de Cálculo do Ajuste a } \\
\text { Valor Recuperável }\end{array}$ & $\begin{array}{l}\text { Será facultado ao ente escolher a metodologia que melhor retrate sua expectativa } \\
\text { de recebimento, sendo obrigatória a divulgação da metodologia utilizada e da } \\
\text { memória de cálculo de notas explicativas. }\end{array}$ \\
\hline $\begin{array}{l}\text { Exclusão dos } \\
\text { Lançamentos referentes à } \\
\text { Cobrança Terceirizada }\end{array}$ & $\begin{array}{l}\text { Exclusão dos lançamentos referentes à cobrança terceirizada devido à } \\
\text { contabilização e questionamento acerca da constitucionalidade da Resolução do } \\
\text { Senado Federal } n^{\circ} 33 \text {, de } 13 \text { de julho de } 2006 \text { (ADI 3786). }\end{array}$ \\
\hline Exclusão de Lançamentos & Exclusão dos lançamentos contábeis padronizados (LCP). \\
\hline $\begin{array}{l}\text { Exclusão do Conjunto de } \\
\text { Lançamentos }\end{array}$ & Exclusão do conjunto de lançamentos padronizados (CLP). \\
\hline Exclusão de Lançamentos & Exclusão de lançamentos típicos. \\
\hline $\begin{array}{l}\text { Exclusão de Relações de } \\
\text { Contas }\end{array}$ & $\begin{array}{l}\text { Exclusão da relação de contas do Plano de Contas Aplicados ao Setor Público } \\
\text { (PCASP). }\end{array}$ \\
\hline
\end{tabular}

Fonte: Manual de Contabilidade Aplicada ao Setor Público, Síntese das Alterações da $5^{\text {a }}$ para a $6^{\text {a }}$ Edição, 2015 (Adaptado pelos autores)

Aplicou-se a análise quantitativa com o objetivo de verificar a sensibilidade e relação entre as variáveis relacionadas à dívida ativa do Estado do Rio de Janeiro. Tal análise justifica-se, pois, a dívida ativa sofre influências de fatores endógenos e exógenos da Administração Pública, tais como: registros de Certidões de Dívidas Ativas prescritas; falta de controle sobre créditos que deveriam ser executados pelo Poder Público; inércia do Judiciário 
na tramitação dos processos; diferentes formas de políticas públicas de administrar e controlar os créditos pelos governos; falta de continuidade de políticas públicas entre outros fatores.

Aplicando-se o teste de Regressão Simples, para os saldos referentes à Dívida Ativa Tributária e Não Tributária e Provisão para Perdas com Dívida Ativa, no período de 2010 a 2014, obteve-se os seguintes resultados para análise:

Tabela 1 - Estatística de Regressão Simples

\begin{tabular}{lr}
\hline R múltiplo & 0,588103227 \\
R-Quadrado & 0,345865405 \\
R-quadrado ajustado & $-0,308269189$ \\
Erro padrão & R\$ 8.239,84 milhões \\
Observações & 5 \\
\hline $\begin{array}{l}\text { Fonte: Portal da Transparência, Contadoria, do Estado do Rio de Janeiro. Relatórios de Contas de Gestão de } \\
2010 \text { a } 2014 \text { (Adaptado pelos Autores). }\end{array}$
\end{tabular}

Observa-se que há $58,81 \%$ de correlação entre as variáveis independentes, contas patrimoniais de Dívida Ativa Tributária e Não Tributária, e a variável dependente, conta de Provisão para Perdas com Dívida Ativa; logo, a sensibilidade existente entre a Provisão para Perdas com Dívida Ativa e os registros dos estoques das Dívidas Ativas Tributária e Não Tributária é moderada, sofrendo variações quase que proporcionais.

Isso é verificado também pelo resultado do R-Quadrado, em que 34,58\% da variabilidade dos saldos apresentados na conta de Provisão para Perdas com Dívida Ativa são explicadas pelo modelo de regressão adotado. O R-quadrado ajustado apresentou $-30,83 \%$ levando em conta o número de variáveis independentes. Já o erro padrão de $\mathrm{R} \$ 8.239,84$ milhões mostra o desvio padrão do modelo, dado pela raiz quadrada da variância.

Tabela 2 - ANOVA Interseção

\begin{tabular}{|c|c|c|c|c|c|c|c|c|}
\hline & Coeficientes & $\begin{array}{c}\text { Erro } \\
\text { padrão }\end{array}$ & Stat $t$ & valor $-P$ & $\begin{array}{c}95 \% \\
\text { inferiores }\end{array}$ & $\begin{array}{c}95 \% \\
\text { superiores }\end{array}$ & $\begin{array}{c}\text { Inferior } \\
95,0 \%\end{array}$ & $\begin{array}{c}\text { Superior } \\
95,0 \%\end{array}$ \\
\hline Interseção & $\begin{array}{l}-30.688 \\
\text { milhões }\end{array}$ & $\begin{array}{c}25.426 \\
\text { milhões }\end{array}$ & $-1,21$ & 0,35 & $\begin{array}{l}-140.090 \\
\text { milhões }\end{array}$ & $\begin{array}{c}78.713 \\
\text { milhões }\end{array}$ & $\begin{array}{l}-140.090 \\
\text { milhões }\end{array}$ & $\begin{array}{c}78.713 \\
\text { milhões }\end{array}$ \\
\hline $\begin{array}{c}\text { Variável } \\
\text { X } 1\end{array}$ & $\begin{array}{c}\text {-1,06 } \\
\text { milhões }\end{array}$ & $\begin{array}{c}\text { 1,23 } \\
\text { Milhões }\end{array}$ & $-0,87$ & 0,48 & $\begin{array}{c}-6,34 \\
\text { milhões }\end{array}$ & $\begin{array}{c}\text { 4,21 } \\
\text { milhões }\end{array}$ & $\begin{array}{r}-6,34 \\
\text { milhões }\end{array}$ & $\begin{array}{c}\text { 4,21 } \\
\text { milhões }\end{array}$ \\
\hline $\begin{array}{c}\text { Variável } \\
\text { X } 2\end{array}$ & $\begin{array}{c}27,51 \\
\text { milhões }\end{array}$ & $\begin{array}{c}\text { 47,78 } \\
\text { Milhões }\end{array}$ & 0,58 & 0,62 & $\begin{array}{l}\text {-178,06 } \\
\text { milhões }\end{array}$ & $\begin{array}{l}\text { 233,09 } \\
\text { milhões }\end{array}$ & $\begin{array}{l}-178,06 \\
\text { milhões }\end{array}$ & $\begin{array}{l}\text { 233,09 } \\
\text { milhões }\end{array}$ \\
\hline
\end{tabular}

Fonte: Portal da Transparência, Contadoria, do Estado do Rio de Janeiro. Relatórios de Contas de Gestão de 2010 a 2014 (Adaptado pelos Autores). 
De posse dos quocientes a equação de Regressão Linear Simples, para a amostra analisada, é dada pela seguinte expressão:

\section{Provisão para Perda = -30.688 milhões -1,06 milhões Dívida Ativa Tributária + 27,51 milhões Dívida Ativa Não Tributária}

Aplicando-se a referida equação de Regressão Linear Simples sobre as variáveis independentes, Divida Ativa Tributária e Não Tributária, verifica-se que os resultados se mantiveram dentro do erro padrão de $\mathrm{R} \$ 8.240$ milhões, conforme demonstrado na tabela 3 na coluna Diferença.

Tabela 3 - Teste da Equação de Regressão Linear Simples

\begin{tabular}{|c|c|c|c|c|c|c|c|c|}
\hline Ano & $\begin{array}{c}\text { Interseção } \\
\text { (milhões) }\end{array}$ & $\begin{array}{c}\text { Variável } \\
\times 1\end{array}$ & $\begin{array}{c}\text { Divida } \\
\text { Ativa } \\
\text { Tributária } \\
\text { (milhões) }\end{array}$ & $\begin{array}{c}\text { Variável } \\
\times 2\end{array}$ & $\begin{array}{c}\text { Divida } \\
\text { Ativa Não } \\
\text { Tributária } \\
\text { (milhões) }\end{array}$ & $\begin{array}{c}\text { Provisão } \\
\text { para } \\
\text { Perdas } \\
\text { Estimada } \\
\quad(=)\end{array}$ & $\begin{array}{c}\text { Provisão } \\
\text { para } \\
\text { Perdas } \\
\text { (Registro) }\end{array}$ & Diferença \\
\hline 2010 & -30.688 & $-1,06$ & x 36.607 & 27,51 & x 1.151 & -37.939 & -37.397 & 542 \\
\hline 2011 & -30.688 & $-1,06$ & x 43.133 & 27,51 & x 1.075 & -46.968 & -43.204 & 3.764 \\
\hline 2012 & -30.688 & $-1,06$ & x 49.128 & 27,51 & x 1.337 & -46.128 & -50.374 & -4.246 \\
\hline 2013 & -30.688 & $-1,06$ & x 53.765 & 27,51 & x 1.453 & -47.865 & -55.082 & -7.217 \\
\hline 2014 & -30.688 & $-1,06$ & x 57.905 & 27,51 & x 1.606 & -48.058 & -40.901 & 7.157 \\
\hline
\end{tabular}

Fonte: Portal da Transparência, Contadoria, do Estado do Rio de Janeiro. Relatórios de Contas de Gestão de 2010 a 2014 (Adaptado pelos Autores).

O Estado do Rio de Janeiro adota as diretrizes emanadas pelo MCASP (2015), quanto aos aspectos referentes à escrituração dos eventos acerca da dívida ativa (Registros contábeis pertinentes ao reconhecimento dos direitos a receber em atraso; encaminhamento dos créditos para inscrição em dívida ativa; inscrição em dívida ativa; atualização monetária; ajuste para perdas prováveis na dívida ativa; transferência do longo para o curto prazo; reconhecimento da dívida ativa em espécie; abatimentos; anistias; remissões; e cancelamentos da dívida ativa), de acordo com o Manual da Dívida Ativa (RIO DE JANEIRO, 2015).

A Tabela 4 evidencia os créditos que estão em fase de cobrança administrativa e encontram-se classificados no curto prazo, de acordo com a expectativa de sua realização, observando as prescrições dadas pela NBC T 16.1 - Classificação dos Elementos Patrimoniais em Circulante e Não Circulante, instituída pela Resolução CFC 1.129/08. 
Revista Ambiente Contábil - ISSN 2176-9036 - UFRN - Natal-RN. v. 8. n. 1, p. 205 - 225, jan./jun. 2016.

Tabela 4 - Inscrição de Dívida Ativa do Estado do Rio de Janeiro - 2010 a 2014 (Em Milhões de Reais)

\begin{tabular}{lccccccccc}
\hline Descrição & 2010 & VH & 2011 & VH & 2012 & VH & 2013 & VH & 2014 \\
\hline $\begin{array}{l}\text { Créditos Inscritos em } \\
\begin{array}{l}\text { Dívida Ativa } \\
\quad \text { Dívida Ativa }\end{array}\end{array}$ & 324 & $-32 \%$ & 220 & $193 \%$ & 644 & $-58 \%$ & 269 & $39 \%$ & 374 \\
$\begin{array}{l}\text { Tributária } \\
\quad \text { Dívida Ativa Não }\end{array}$ & 318 & $-34 \%$ & 211 & $199 \%$ & 631 & $-59 \%$ & 261 & $40 \%$ & 366 \\
$\quad$ Tributária & 7 & $27 \%$ & 9 & $55 \%$ & 13 & $-41 \%$ & 8 & $5 \%$ & 8 \\
\hline
\end{tabular}

Fonte: Portal da Transparência, Contadoria, do Estado do Rio de Janeiro. Relatórios de Contas de Gestão de 2010 a 2014. Demonstrativos Contábeis e Notas Explicativas - Consolidado de 2010 a 2014. (Adaptado pelos Autores).

De acordo com o artigo 176, parágrafo $6^{\circ}$, da Constituição Estadual do Rio de Janeiro compete a Procuradoria Geral do Estado do Rio de Janeiro (PGE-RJ) a cobrança judicial e extrajudicial da dívida ativa.

Nota-se que, em síntese, os créditos vencidos, reconhecidos como créditos a receber no ativo do órgão ou entidade de origem do crédito, poderão ser encaminhados para inscrição em dívida ativa, a fim de proceder às cobranças administrativas ou iniciar a fase de execução judicial.

Os procedimentos de cobranças administrativas são de suma importância para evitar possíveis frustrações na arrecadação do Estado, impactando na programação orçamentária e financeira do exercício, além de estimular o aparecimento de novos inadimplentes e também onerar os bons pagadores.

Nesta linha, os débitos de menor valor, em regra, são cobrados administrativamente, através de envio de notificações com as guias de pagamento da dívida aos sujeitos passivos (contribuintes ou responsáveis); os débitos inscritos em dívida ativa superiores a aproximadamente R \$ 5,8 mil são cobrados por meio de execução fiscal. A PGE-RJ conta também com a possibilidade de protesto da dívida nas esferas administrativa e judicial.

A Tabela 5 mostra o comportamento dos créditos em processo de inscrição de dívida ativa, os já inscritos e a provisão para perdas de dívida ativa, registrados no longo prazo, no período de 2010 a 2014.

Tabela 5 - Créditos em Dívida Ativa do Estado do Rio de Janeiro - 2010 a 2014 (Em Milhões de Reais)

\begin{tabular}{|c|c|c|c|c|c|c|c|c|c|}
\hline Descrição & 2010 & $\mathrm{VH}$ & 2011 & $\mathrm{VH}$ & 2012 & $\mathrm{VH}$ & 2013 & $\mathrm{VH}$ & 2014 \\
\hline $\begin{array}{l}\text { Crédito em Processo } \\
\text { Inscrição }\end{array}$ & 17 & $-13 \%$ & 14 & $73 \%$ & 25 & $-100 \%$ & - & $0 \%$ & - \\
\hline $\begin{array}{l}\text { Créditos Inscritos em } \\
\text { Dívida Ativa }\end{array}$ & 37.433 & $18 \%$ & 43.988 & $13 \%$ & 49.821 & $10 \%$ & 54.948 & $8 \%$ & 59.136 \\
\hline $\begin{array}{l}\text { Dívida Ativa } \\
\text { Tributária }\end{array}$ & 36.289 & $18 \%$ & 42.922 & $13 \%$ & 48.498 & $10 \%$ & 53.503 & $8 \%$ & 57.539 \\
\hline $\begin{array}{l}\text { Dívida Ativa Não } \\
\text { Tributária }\end{array}$ & 1.144 & $-7 \%$ & 1.066 & $24 \%$ & 1.324 & $9 \%$ & 1.445 & $11 \%$ & 1.598 \\
\hline $\begin{array}{l}\text { Provisão para Perdas de } \\
\text { Dívida Ativa }\end{array}$ & -37.075 & $17 \%$ & -43.204 & $15 \%$ & -49.821 & $9 \%$ & -54.529 & $-25 \%$ & -40.664 \\
\hline
\end{tabular}

Fonte: Portal da Transparência, Contadoria, do Estado do Rio de Janeiro. Relatórios de Contas de Gestão de 2010 a 2014. Demonstrativos Contábeis e Notas Explicativas - Consolidado de 2010 a 2014. (Adaptado pelos Autores).

$\mathrm{Na}$ análise dos créditos inscritos em dívida ativa de natureza tributária verifica-se o crescimento do saldo ao longo do período (2010-2011: +18\%; 2011-2012: +13\%; 2012-2013: 
+10\%; e 2013-2014: + 8\%). Este comportamento demonstra que o fluxo de ingressos de receitas inscritas em dívida ativa é superior às baixas.

O Estado do Rio de Janeiro não utiliza o regime de competência para o registro dos créditos de natureza tributária, mas, apenas para os créditos não tributários (RIO DE JANEIRO, 2015). Como método alternativo, o reconhecimento dos créditos de natureza tributária se faz como um direito a receber em contrapartida a uma variação patrimonial aumentativa ou a conta de ajuste de exercícios anteriores, de acordo com o lapso temporal da ocorrência do fato gerador do tributo.

Neste contexto, torna-se importante a adequação dos ingressos de natureza tributária obedecendo ao regime de competência quando da ocorrência do fato gerador da receita, no momento da etapa do lançamento desta, para que posteriormente fatos como arrecadação ou baixa do crédito possam ser monitorados, pois a inscrição em dívida ativa reflete um fato permutativo alterando tão somente a classificação do crédito a receber já classificado.

Os créditos de natureza não tributária inscritos em dívida ativa, com exceção do período de 2011 (2010-2011: -7\%), se mantiveram numa crescente (2011-2012: 24\%; 20122013: +9\%; 2013-2014: 11\%). Estes créditos, como dito, são registrados em obediência ao regime de competência. Logo, infere-se que os créditos de natureza não tributária passaram a ser controlados tanto pela instituição, quanto pela sociedade, através dos saldos registrados no subsistema patrimonial com o acréscimo de receita, dando mais transparência na gestão fiscal. Isso é de extrema relevância, pois fortalece os controles da Administração Pública no sentido de evitar que os referidos créditos vencidos e inscritos em dívida ativa "caduquem", pelo instituto da prescrição, por falta de execução dos direitos a receber a favor da Fazenda Pública.

Como forma de controle do estoque de dívida ativa o Estado se utiliza da mensuração do ajuste para perdas com créditos em dívida ativa, materializando-se nos demonstrativos como uma conta de natureza redutora, retratando de forma prudente e realista os saldos líquidos, refletindo a essência dos princípios da oportunidade e da prudência e do MCASP (2015). As provisões podem se constituir pela média percentual dos recebimentos ao longo dos três últimos exercícios, pela inscrição dos valores históricos das dívidas vencidas e não pagas, pela inscrição dos créditos suspensos que estavam sendo questionados na esfera administrativa e que posteriormente foram indeferidos os recursos a favor do Estado. Podem também refletir valores prescritos de cobrança ao sujeito passivo (contribuinte ou responsável) entre outras situações.

Observa-se que as Provisões para Perdas de Dívida Ativa, à exceção do período de 2014 (2013-2014: -25\%), se mantiveram em alta (2010-2011: +17\%; 2011-2012: +15\%; e 2012-2013: +9\%). A principal justificativa da redução no ano de 2014 decorreu da mudança de metodologia de cálculo proposta pela Procuradoria da Dívida Ativa do Estado do Rio de Janeiro, através do Ofício PGE/PG-5/NTJ 64/2013, e aceita pelo Tribunal de Contas do Estado do Rio de Janeiro, a qual deverá ser observada por todos os entes das administrações direta e indireta do Estado do Rio de Janeiro.

A Tabela 6 retrata a movimentação do estoque da dívida ativa tributária e não tributária no período de 2010 a 2014. 
Revista Ambiente Contábil - ISSN 2176-9036 - UFRN - Natal-RN. v. 8. n. 1, p. 205 - 225, jan./jun. 2016.

Tabela 6 - Estoque da Dívida Ativa do Estado do Rio de Janeiro - 2010 a 2014 (Em Milhões de Reais)

\begin{tabular}{lccccccccc}
\hline Descrição & 2010 & VH & 2011 & VH & 2012 & VH & 2013 & VH & 2014 \\
\hline Saldo Inicial & 34.812 & $8 \%$ & 37.757 & $17 \%$ & 44.207 & $15 \%$ & 50.642 & $9 \%$ & 55.193 \\
(+) Inscrições & 5.075 & $25 \%$ & 6.336 & $9 \%$ & 6.895 & $-36 \%$ & 4.398 & $-12 \%$ & 3.892 \\
(-) Baixas & -3.587 & $-52 \%$ & -1.734 & $81 \%$ & -3.136 & $-37 \%$ & -1.967 & $53 \%$ & -3.004 \\
(+) Atualização & 1.457 & $50 \%$ & 2.187 & $33 \%$ & 2.899 & $1 \%$ & 2.925 & $10 \%$ & 3.230 \\
(+/-) Outros & - & $0 \%$ & -339 & $-34 \%$ & -223 & $260 \%$ & -805 & $-107 \%$ & 56 \\
Saldo Final & 37.757 & $17 \%$ & 44.207 & $15 \%$ & 50.642 & $9 \%$ & 55.193 & $8 \%$ & 59.366 \\
\hline
\end{tabular}

Fonte: Portal da Transparência, Contadoria, do Estado do Rio de Janeiro. Relatórios de Contas de Gestão de 2010 a 2014. Demonstrativos Contábeis e Notas Explicativas - Consolidado de 2010 a 2014. (Adaptado pelos Autores).

Percebe-se que o saldo final retrata o somatório dos "Créditos Inscritos em Dívida Ativa" em fase de cobrança administrativa, registrados no curto prazo (Tabela 4), e os "Créditos Inscritos em Dívida Ativa", escriturados no longo prazo (Tabela 5).

Torna-se oportuno salientar que os 5 (cinco) anos para atividade de lançamento do crédito refletem o período decadencial. Se for realizada a atividade de lançamento da receita e ocorrer o seu pagamento dentro do vencimento da obrigação, haverá sua extinção; caso contrário, o fisco terá mais 5 (cinco) anos para proceder com a inscrição em dívida ativa, a contar da data do lançamento, em regra, período prescricional.

No processo de inscrição em dívida ativa é gerada a Certidão de Dívida Ativa - CDA. A CDA é peça fundamental para a propositura da ação de execução por parte do Estado para recebimento da obrigação do sujeito passivo que está em mora.

Desta forma, o prazo que o fisco dispõe para suas atividades de cobranças das receitas públicas, em princípio, pode chegar até 10 (dez) anos na esfera administrativa, caso não haja quaisquer questionamentos e/ou discussões em $1^{\mathrm{a}}$ e $2^{\mathrm{a}}$ instâncias, em vias administrativa e/ou judicial, que possam vir a suspender os prazos decadencial (consulta administrativa) ou prescricional. Tais trâmites explicam o comportamento crescente ocorrido no estoque da dívida ativa tributária e não tributária no período (2010-2011: +17\%; 2011-2012: +15\%; 2012-2013: 9\%; 2013-2014: +8\%).

O Estado do Rio de Janeiro tem envidado esforços para recuperação dos créditos inscritos em dívida ativa com medidas que possam retirar determinados incentivos concedidos aos sujeitos passivos em débitos. Em notícia publicada pela Subsecretaria de Comunicação, no portal de Imprensa do RJ (2015), ${ }^{1}$ foi divulgado um total de 121.766 processos de execução de débitos tributários que tramitavam até o término de 2014 no Tribunal de Justiça do Estado do Rio de Janeiro, sendo 60\% destes na Capital.

Percebe-se que o bojo da questão está na dificuldade de recebimento dos valores em mora, pela complexidade e desafios que envolvem os procedimentos de cobrança nas esferas administrativa e judicial.

As falhas que corroboram para o crescimento do estoque da dívida ativa podem ser diversas a exemplo da omissão do procedimento de inscrição em dívida ativa ou execução do referido crédito, acarretando, em alguns casos, a prescrição do direito da Fazenda Estadual em cobrar tais créditos. A ocorrência deste caso torna difícil a tarefa do Estado de materializar a cobrança com sucesso, mantendo, então, o crédito registrado no patrimônio com chances remotas de recebimento futuro.

Outra fragilidade apontada na arrecadação e cobrança está na morosidade da movimentação forense (tombamento ao arquivamento do processo). São diversos os motivos

\footnotetext{
${ }^{1}$ Imprensa do RJ. Notícias. Governo. Subsecretaria de Comunicação do Estado. Governo do Estado Aperta o Cerco Contra Devedores. 04/02/15. Disponível em: http://www.rj.gov.br/web/imprensa/exibeconteudo?articleid $=2325289$.
} 
desta demora, tais como: a complexidade das discussões que envolvem o mérito; muitos processos têm mais de 20 anos e estão com falhas formais e/ou materiais; o fluxo de trabalho intenso nas varas fazendárias entre outros. Enquanto a situação persiste os créditos de dívida ativa ficam suspensos até que a decisão seja transitada em julgado, refletindo, assim, no aumento do congestionamento de processos nas serventias fazendárias.

Neste contexto, infere-se o quanto intricado se torna a gestão de ações que mirem no consumo do estoque da dívida ativa, com eficiência.

De acordo com o Relatório de Estoque da Dívida Ativa (2014) as deduções do estoque podem ocorrer por motivos variados, a saber: pela extinção através da remissão total ou parcial; cancelamento decorrente de decisão judicial ou administrativa desfavorável à Fazenda Pública; cancelamento por inscrição indevida; cancelamento por extinção do pagamento da obrigação tributária anterior ao processo de inscrição de dívida ativa; cancelamentos por resíduos de valores referentes a pagamentos anteriores; por extinção pelo pagamento à vista, por suspensão através do parcelamento ou pela exclusão do débito fiscal com a anistia.

A Tabela 7 aponta para o quantitativo de certidões de dívida ativa que foram canceladas devido à prescrição dada em sede administrativa e judicial, remissão, inscrição indevida, liquidação amigável e judicial entre outros casos.

\section{Tabela 7 - Cancelamento de Certidões Inscritas em Dívida Ativa no Ano de 2014}

\begin{tabular}{lcccc}
\multicolumn{1}{c}{ Descrição } & $\begin{array}{c}\text { Quantidade de } \\
\text { Certidões }\end{array}$ & $\begin{array}{c}\text { Ufir`s (Em } \\
\text { milhares) }\end{array}$ & $\begin{array}{c}\text { Ufir em } \\
(31 / 12 / 2014)\end{array}$ & $\begin{array}{c}\text { Total Cancelamento } \\
\text { (Em Milhares de } \\
\text { Reais) }\end{array}$ \\
\hline & & & & 1.848 \\
$\begin{array}{l}\text { Por Decisão Administrativa - } \\
\text { Prescrição }\end{array}$ & 243 & 726 & 2,5473 & 774.114 \\
$\begin{array}{l}\text { Por Decisão Administrativa - } \\
\text { Outros }\end{array}$ & 293.816 & 303.896 & 2,5473 & 75.928 \\
$\begin{array}{l}\text { Por Decisão Judicial - } \\
\text { Prescrição }\end{array}$ & 423 & 29.807 & 2,5473 & 670.785 \\
& & & & 37.962 \\
Por Decisão Judicial - Outros & 940 & 263.332 & 2,5473 & 352.272 \\
Por Remissão Total & 91 & 14.903 & 2,5473 & 42.536 \\
Por Inscrição Indevida & 1.106 & 138.292 & 2,5473 & 677.505 \\
Liquidação Amigável & 16.279 & 16.698 & 2,5473 & 2.632 .950 \\
Liquidação Judicial & 4.784 & 265.970 & 2,5473 & \\
Totais & 317.682 & 1.033 .624 & & \\
\hline Fonte: Portal Ta Transparen
\end{tabular}

Fonte: Portal da Transparência, Contadoria, do Estado do Rio de Janeiro. Relatórios de Contas de Gestão de 2014. Estoque da Dívida Ativa Exercício de 2014. (Adaptado pelos Autores).

Uma das medidas do Governo do Estado do Rio de Janeiro foi a implementação de incentivos para a regulação dos débitos, através de parcelamentos com redução da multa, juros de mora e a possibilidade de créditos com precatórios judiciais, embasados nas Leis ${ }^{\text {os }}$ 5.647/10 e 6.136/11 e no convênio Confaz ICMS n ${ }^{\circ}$ 128/13. Outras ações foram trazidas pelas Leis $\mathrm{n}^{\text {os }}$ 6.357/12 e 6.931/14 dando remissão e anistias de ICMS e IPVA, descongestionando as cobranças nas esferas administrativa e judicial, conforme se observa no elevado quantitativo de certidões canceladas na Tabela 6 (2013-2014: $+53 \%)$.

Ressalta-se que tais procedimentos, apesar de buscarem o imediatismo do consumo do estoque da dívida ativa, possuem algumas fragilidades, a exemplo de: beneficiar os "maus pagadores"; riscos de questionamentos futuros pelas Cortes de Controle Externo devido à característica de renuncia de receitas públicas (R \$ 2.693 Milhões, em 2014, Tabela 7).

A Tabela 8 demonstra o resultado dos esforços despendidos no consumo dos estoques de dívida ativa dados pelo Governo do Estado do Rio de Janeiro. 


\begin{tabular}{|c|c|c|c|c|c|c|c|c|c|}
\hline Descrição & 2010 & VH & 2011 & VH & 2012 & $\mathrm{VH}$ & 2013 & VH & 2014 \\
\hline \multicolumn{10}{|l|}{$\begin{array}{l}\text { Multas/Juros de Mora } \\
\text { da Dívida Ativa }\end{array}$} \\
\hline Tributos & 298 & $-76 \%$ & 73 & $110 \%$ & 153 & $-24 \%$ & 116 & $-33 \%$ & 78 \\
\hline \multicolumn{10}{|l|}{ Multa/Juros de Mora } \\
\hline $\begin{array}{l}\text { da Dívida Ativa - } \\
\text { Outras Receitas }\end{array}$ & 3 & $-67 \%$ & 1 & $600 \%$ & 7 & $-71 \%$ & 2 & $0 \%$ & 2 \\
\hline \multicolumn{10}{|l|}{ Receita da Dívida } \\
\hline Ativa Tributária & 603 & $-64 \%$ & 215 & $191 \%$ & 626 & $0 \%$ & 624 & $-30 \%$ & 434 \\
\hline \multicolumn{10}{|l|}{ Receita da Dívida } \\
\hline Ativa Não Tributária & 54 & $-72 \%$ & 15 & $20 \%$ & 18 & $-17 \%$ & 15 & $-33 \%$ & 10 \\
\hline Total & 958 & $-68 \%$ & 304 & $164 \%$ & 804 & $-6 \%$ & 757 & $-31 \%$ & 524 \\
\hline
\end{tabular}

Fonte: Portal da Transparência, Contadoria, do Estado do Rio de Janeiro. Relatórios de Contas de Gestão de 2010 a 2014. Demonstrativos Contábeis e Notas Explicativas - Consolidado de 2010 a 2014. (Adaptado pelos Autores).

Com exceção dos anos de 2010 e 2012, os demais exercícios tiveram uma cobrança não tão satisfatória se comparados com aqueles. Tal fato ressalta o quão difícil é a gestão dos créditos em dívida ativa tributária e não tributária, tornando-se imprescindíveis ações contínuas de melhoria sobre os controles internos, cobranças administrativas, cobranças judiciais, com intuito de maximizar a entrada de receitas desta natureza.

\section{CONCLUSÃO}

A abordagem sobre as principais ações realizadas pelo Estado do Rio de Janeiro na gestão do estoque da dívida ativa, no período de 2010 a 2014, presume-se alcançada, sendo que algumas considerações serão a seguir apresentadas.

A sensibilidade existente entre a Provisão para Perdas com Dívida Ativa e os registros dos estoques das Dívidas Ativas Tributária e Não Tributária demonstrou-se moderada, sofrendo variações quase que proporcionais, de acordo com os testes estatísticos de regressão simples e de interseção pela função ANOVA.

O Estado do Rio de Janeiro ainda não utiliza o regime de competência nos registros dos créditos da dívida ativa tributária. Entretanto, os créditos de dívida ativa não tributária são escriturados em obediência àquele regime.

O registro dos créditos em dívida ativa não tributária, obedecendo ao princípio da competência, ocasiona em mais transparência para instituição e sociedade, fortalecendo os controles internos da instituição e social.

O Estado se utiliza da mensuração do ajuste para perdas com créditos em dívida ativa, materializando-se nos demonstrativos como uma conta de natureza redutora, retratando de forma prudente e realista os saldos líquidos, refletindo a cerne dos princípios da oportunidade e da prudência.

O crescimento do estoque de dívida ativa tem forte influência sobre os trâmites legais que o regem, através da obediência dos prazos decadenciais e prescricionais que o fisco 
dispõe para suas atividades de cobranças das receitas públicas que, em regra, pode chegar até 10 (dez) anos na esfera administrativa, caso não ocorram quaisquer questionamentos e/ou discussões em $1^{\mathrm{a}}$ e $2^{\mathrm{a}}$ instâncias, que possam vir a suspender os prazos decadencial (consultas administrativas) ou prescricional. Diante disto, infere-se que ações de cobranças amigáveis tendem a ser eficazes para o incremento do fluxo das receitas arrecadas para o sujeito ativo.

Os esforços conjuntos envidados pelos órgãos do Estado do Rio de Janeiro levaram ao saneamento de determinados créditos considerados incobráveis ocasionando em alguns casos o cancelamento das certidões por diversos motivos como: créditos prescritos em sede administrativa ou judicial; remissão; inscrição indevida; liquidação amigável ou judicial. Fator de suma importância para o fortalecimento dos controles internos e salvaguarda das certidões que tem chances reais de exequibilidade.

Verificou-se que o consumo do estoque de dívida ativa se justificou também pelo viés político, por meio da concessão de incentivos fiscais de remissões e anistias com vistas à regularização de débitos. Tais ações beneficiam os maus pagadores e por consequência oneram aqueles sujeitos passivos que pagam suas obrigações fiscais em dia para com o Estado.

O acervo expressivo de processos nas varas de fazenda pública do judiciário espelha que grande parte dos créditos inscritos em dívida ativa está em fase de litígio e com efeito de suspensão, quanto à expectativa de recebimento, justificando, em parte, a necessidade de um controle contínuo sobre a idade, expectativa de recebimento e ganho da ação.

Destarte, sugere-se como alvo de outras pesquisas acadêmicas uma abordagem mais detalhada sob os regimes contábeis aplicados para a receita pública, considerando na investigação as fases, os sistemas e subsistemas, bem como as posições doutrinárias. Também, torna-se interessante o acompanhamento da dívida ativa em outros entes da Administração Pública, decorrentes das alterações normativas vigentes, explorando seus efeitos quantitativos e qualitativos, sob as óticas das eficiências dos controles existentes e da política de arrecadação e cobrança.

\section{REFERÊNCIAS}

BRASIL. Constituição da República Federativa do Brasil. Diário Oficial [da] República Federativa do Brasil, Brasília, DF, 5 dez. 1998. Disponível em: $<$ http://www.planalto.gov.br/ccivil_03/constituicao/constituicaocompilado.htm>. Acesso em 9 jan. 2015

BRASIL. Secretaria do Tesouro Nacional. Manual de Contabilidade Aplicada ao Setor Público. 6. ed. Diário Oficial [da] República Federativa do Brasil,Brasília, DF, 2015. Disponível em: < http://www.tesouro.fazenda.gov.br/mwginternal/de5fs23hu73ds/progress?id=cMU8s6ujYkU_kN34YKJsc57WQi7u5to2cUivJhQvxoo ,\&dl>. Acesso em: 9 jan. 2015.

BRASIL. Lei Complementar $\mathrm{n}^{0}$ 101, de 04 de maio de 2000. Estabelece normas de finanças públicas voltadas para a responsabilidade na gestão fiscal e dá outras providências. Diário Oficial [da] República Federativa do Brasil, Brasília, DF, 5 mai. 2000. Disponível em: <https://www.planalto.gov.br/ccivil_03/LEIS/LCP/Lcp101.htm>. Acesso em: 9 jan. 2015.

BRASIL. Lei n ${ }^{\circ}$ 4.320, de 17 de março de 1964. Estatui Normas Gerais de Direito Financeiro para elaboração e controle dos orçamentos e balanços da União, dos Estados, dos Municípios e do Distrito Federal. Diário Oficial [da] República Federativa do Brasil,, Brasília, DF, 23 
mar. 1964. Disponível em: <https://www.planalto.gov.br/ccivil_03/Leis/L4320.htm>. Acesso em: 9 jan. 2015.

BRASIL. Lei $n^{0}$ 5.172, de 25 de outubro de 1996. Dispõe sobre o Sistema Tributário Nacional e institui normas gerais de direito tributário aplicáveis à União, Estados e Municípios. . Diário Oficial [da] República Federativa do Brasil, Brasília, DF, 27 out. 1966. Disponível em: 〈http://www.planalto.gov.br/ccivil_03/Leis/L5172.htm>. Acesso em: 9 jan. 2015.

BRASIL. Secretaria do Tesouro Nacional. Portaria STN no 437 de 12 de junho de 2012. Aprova as Partes II - Procedimentos Contábeis Patrimoniais, III - Procedimentos Contábeis Específicos, IV - Plano de Contas Aplicado ao Setor Público, V - Demonstrações Contábeis Aplicadas ao Setor Público, VI - Perguntas e Respostas e VII - Exercício Prático, da $5^{\text {a }}$ edição do Manual de Contabilidade Aplicada ao Setor Público (MCASP). Diário Oficial [da] República Federativa do Brasil, Brasília, DF, 2012. Disponível em: < http://www3.tesouro.gov.br/legislacao/download/contabilidade/Portaria_STN_437_MCASP.p df>. 9 jan. 2015.

BRASIL. Tesouro Nacional. Portaria STN no 828, de 14 de dezembro de 2011. Altera o prazo de implementação do Plano de Contas Aplicado ao Setor Público e dá outras providências. Diário Oficial [da] República Federativa do Brasil, Brasília, DF, 2011. Disponível em: < http://www3.tesouro.gov.br/legislacao/download/contabilidade/PortSTN_828_20111214.pdf> . Acesso em: 9 jan. 2015

CASTRO, Domingos Poubel de; GARCIA, Leice Maria; Contabilidade pública no Governo Federal: guia para reformulação do ensino e implantação da lógica do SIAFI nos governos municipais e estaduais com utilização do Excel. São Paulo: Atlas, 2004. ISBN 85224-3847-1.

CRUVINEL, D.P.; LIMA, D.V. Adoção do regime de competência no setor público brasileiro sob a perspectiva das normas brasileiras e internacionais de contabilidade. Revista de Educação e Pesquisa em Contabilidade (REPeC), v.5, n.3, p.69-85. 2011.

DALFOVO, Oscar; MAÇANEIRO, Wanderley. Contabilidade pública: limites e possibilidades do contador. Revista Interdisciplinar Científica Aplicada, Blumenau, v.2, n.1, p.01-14, Sem I. 2008. ISSN 1980-7031.

DARÓS, Leandro Luís; PEREIRA, Adriano de Souza. Análise das normas brasileiras de contabilidade aplicadas ao setor público - NBCASP: mudanças e desafios para a contabilidade pública. In. Congresso USP de Iniciação Científica, 6, 2009. Anais. São Paulo: USP, 2009.

CONSELHO FEDERAL DE CONTABILIDADE. Resolução CFC $\mathbf{n}^{\mathbf{0}} \mathbf{7 5 0}$, de 29 de dezembro de 1993. Dispõe sobre os Princípios Fundamentais de Contabilidade (PFC). Disponível em:< http://www.cfc.org.br/>. Acesso em: 8 set. 2015.

RIO DE JANEIRO. Manual da Dívida Ativa. Coordenação de Estudos e Manuais. Controladoria Geral do Estado do Rio de Janeiro. Rio de Janeiro: 12 fev. 2015. Disponível em:

<http://www.fazenda.rj.gov.br/sefaz/content/conn/UCMServer/path/Contribution\%20Folders/ contadoria/manuais/principal/Manual\%20da\%20Divida\%20Ativa\%2021-05-2015.pdf?lve>. Acesso em: 4 set. 2015. 
RIO DE JANEIRO. Portal da Transparência. Portais do Estado do Rio de Janeiro. Relatórios Contábeis. Relatórios das Contas de Gestão. Rio de Janeiro: Contadoria. 2010 a 2014. Disponível em: <http://www.fazenda.rj.gov.br/sefaz/faces/menu_structure/sitios/sitioscontadorianavigation/folder3/ur145?_afrLoop=671699750855000\&datasource=UCMServer\%23dDocNa me\%3A1170046\&_adf.ctrl-state=w9wg4xmcr_730>. Acesso em: 4 set. 2015

FEIJÓ, Paulo Henrique. Entrevista. Entrevistador: Revista do Tribunal de Contas do Estado de Minas Gerais. Ano 1, n. 1 (dez-1983- ). Belo Horizonte: Tribunal de Contas do Estado de Minas Gerais. Out a Dez 2012. N. 4. V. 85. Ano XXXX. ISSN 0102-1052. Disponível em: <http://revista.tce.mg.gov.br/Content/Upload/Materia/1721.pdf>. Acesso em: 9 jan. 2015.

GIUBERTI, Ana Carolina. Dívida Ativa e Capacidade Administrativa: Novos Elementos no Debate Sobre a Eficiência na Arrecadação Fiscal dos Estados Brasileiros. Seja Assinante da Estudos Econômicos, p. 22, 2010.

JUND, Sérgio. Administração, orçamento e contabilidade pública: teoria e 830 questões. 2. ed. Rio de Janeiro: Elsevier, 2006.

KOHAMA, Heilio. Contabilidade pública: teoria e prática. São Paulo: Atlas, 2006. 224-3019-5.

Contabilidade Pública: teoria e prática. 8. ed. São Paulo: Atlas, 2001. ISBN 85-

LIMA, D. V.; SANTANA, C. M.; GUEDES, M. A. As normas brasileiras de contabilidade aplicadas ao setor público e a legislação contábil pública brasileira: uma análise comparativa à luz da teoria contábil. Contabilidade, Gestão e Governança, Brasília, v. 12, n. 2, p. 15-23, mai./ago., 2009.

LIMA, Diana Vaz de; CASTRO, Róbson Gonçalves de. Contabilidade pública: integrando União, Estados e Municípios (Siaf e Siafem). 3. ed. São Paulo: Atlas, 2007.

MARCONI, Marina de Andrade, LAKATOS, Eva Maria. Fundamentos de Metodologia Científica. 6 ed. São Paulo: Atlas, 2005.

OLIVEIRA, Marcello Sartore de. Controle da Dívida Ativa: um estudo sob a ótica da Gestão Municipal e do Poder Judiciário. 2013. 145 f. Orientador: Waldir Jorge Ladeira dos Santos. Dissertação (Mestrado) - Universidade Estadual do Rio de Janeiro, Faculdade de Administração e Finanças.

PIMENTEL, Alessandra. O método da análise documental: seu uso numa pesquisa historiográfica. Cadernos de pesquisa. São Paulo, n. 114, nov. 2001 . Disponível em $<$ http://www.scielo.br/scielo.php?script=sci_arttext\&pid=S0100-

$15742001000300008 \& \operatorname{lng}=$ pt\&nrm=iso $>$. Acesso em 05 nov. 2014.

QUITANA, Alexandre Costa; MACHADO, Daiane Pias; QUARESMA, Jozi Cristiane da Costa; MENDES, Roselaine da Cruz. Contabilidade pública: de acordo com as novas normas brasileiras de contabilidade aplicadas ao setor público e a lei de responsabilidade fiscal. São Paulo: Atlas, 2011. ISBN 978-85-224-6121-9.

RAUPP, Fabiano Maury; BEUREN, Ilse Maria. Metodologia da pesquisa aplicável às ciências sociais. Como elaborar trabalhos monográficos em contabilidade: teoria e prática, v. 3, p. 76-97, 2003. 
SLOMSKI, Valmor; Manual de contabilidade pública: um enfoque na contabilidade municipal, de acordo com a Lei de Responsabilidade Fiscal. 2. ed. São Paulo: Atlas, 2003. ISBN 85-224-3386-0.

VICARI JUNIOR, Adauto; CRUZ, Flávio da; GLOCK, José OSVALDO; HERZMANN, Nélio; BARBOSA, Rui Rogério Naschenweng. Comentários à Lei no 4.320: Normas Gerais de Direito Financeiro Orçamentos e Balanços da união, dos Estados, dos Municípios e do Distrito Federal. Comentários ao Substitutivo do Projeto de Lei ${ }^{0} 135 / 96$. 3. ed. São Paulo: Atlas, 2003. ISBN 85-224-3322-4. 